\title{
HOW DO TEACHERS OF PHYSICAL SCIENCES WITH DIFFERENT PROFESSIONAL EXPERIENCES USE VISUAL REPRESENTATIONS WITH EPISTEMIC FUNCTIONS IN THE CLASSROOM
}

\author{
Elisa Saraiva, J. Bernardino Lopes, J. Paulo Cravino, Carla A. Santos \\ University of Trás-os-Montes e Alto Douro, Vila Real, Portugal \\ E-mail: elisasaraiva@hotmail.com, blopes@utad.pt, jcravino@utad.pt, \\ carla.manuela.santos@gmail.com
}

\begin{abstract}
This study aims to clarify the role of visual representations (VR) on the promotion and development of students' epistemic practices (EP) in the physical sciences (PS) classroom. The use of VR is crucial for supporting and developing students' EP (student work in inquiry context).

Research questions: (a) how do teachers trigger the use of VR by students in the classroom? (b) What functions can be attributed to VR in PS classrooms? (c) What is the impact of VR on students' EP? In all questions the dependence on the context and teacher experience will be analyzed.

This is a multicase study with five PS teachers, with different teaching experience, from Portuguese basic schools (students aged 13-15 years).

Multimodal narratives were used (a description of what happens in the classroom, using several types of data collected). Using open coding analysis, categories were found and then cluster analysis was used to find patterns.

Main findings: (a) teacher's efforts are the triggers for the use of VR by students, especially the task proposal; (b) VR can be used as an illustration (does not increase students' $E P$ ) or as epistemic mediator (increases students'EP); (c) all these aspects are dependent on teacher experience.

Key words: Epistemic mediators, students' epistemic practices, teacher mediation, visual representations.

\section{Introduction}

This study aims to highlight the role that visual representations (VR) can play on the promotion and development of students'epistemic practices (EP) in physical sciences classrooms. Most of the studies about students' EP are focussed on the discursive processes in the classroom \{, 1999 \#142;Kelly, 1997 \#143;Crawford, 2000 \#84\} that provided opportunities for students' engagement in practices of production, communication, and evaluation of scientific knowledge, mainly about students' argumentation (Jiménez-Aleixandre \& Erduran, 2008). However, there is a need for research about the student's involvement in scientific practices and discourses that help the student to better understand the nature and development of scientific knowledge (Duschl, 2008). In particular, there is a need for studies that can illustrate how contexts, classroom activities (that sometimes require the use of VR), curriculum materials (that can include VR), and teacher actions can support that in situ development (Kelly \& Duschl, 2002).
\end{abstract}


PROBLEMS

OF EDUCATION

IN THE $21^{\text {st }}$ CENTURY

Volume 42, 2012

98

In the physical science classroom, the teacher must provide epistemic support with his mediation (Sandoval \& Reiser, 2004) for students' engagement in EP, which are determinant for understandings about the nature of science (Duschl, 2000), for competences development (Lopes, Branco, \& Jiménez-Aleixandre, 2011), and inquiry skills development. This concerns student work in certain types of practices to construct knowledge, which emerged from their inquiry activities (Sandoval, 2005) and have as reference the scientific work in the context of scientific production. This characterisation uses epistemological foundations, which arise from the analysis of scientific production in enlarged context (Crawford, Kelly, \& Brown, 2000; Kelly \& Chen, 1999; Reveles, Cordova, \& Kelly, 2004). Through the occurrence of EP students have real opportunities to develop the positive attitudes about science (and ways of doing it) and to construct meanings associated with the practice (Jiménez-Aleixandre \& Reigosa, 2006), developing competences of using scientific knowledge in real context (Lopes et al., 2011).

The use of visual forms of representation for supporting and developing students' inquiry activities (Sandoval, Bell, Coleman, Enyedy, \& Suthers, 2000), rather than being a simply pedagogical option, is crucial in supporting students' engagement with the nature of scientific knowledge building (Kozma, Chin, Russel, \& Marx, 2000; Prain, Tytler, \& Peterson, 2009). VR should be seen as important tools through which students can explore science ideas and clarify for themselves their understandings (Tytler, Prain, \& Peterson, 2007). In the other hand the elaboration and refinement of VR are core epistemic activities within science, used to display data, organise complex information, and promote a shared understanding of scientific phenomena (Kozma, 2003; Wu \& Krajcik, 2006). \{Kozma, 2003 \#113;Kozma, 2003 \#113\} This importance of VR in science justifies that there should be a major emphasis in the physical science classrooms (Prain et al., 2009). There has been little focus on the value of students' use of VR as they are engaged actively with writing tasks in the context of scientific inquiry (Hand \& Choi, 2010). However, there are several studies about the role of VR in students' learning outcomes, which points out that a student's engagement with representations during classroom activities has positive consequences on their conceptual understandings (Hand, Gunel, \& Ulu, 2009; Tytler et al., 2007; Wong, Poo, Hock, \& Kang, 2011). VR can work as tools for cognitive processing and active construction of developing knowledge (Larking \& Simon, 1987) and they can work as tools to mediate learning (Roth, McGinn, \& Bowen, 1998). That's why some studies (Toth, Suthers, \& Lesgold, 2002) instead of focussing on the students' conceptual learning adopted the approach guided by the recognition that VR may provide innovative and successful instructional tools that help students develop fundamental inquiry process skills, i.e., VR can be used with epistemic functions (Jaipal, 2010).

Such research results are important for this work, because VR can work as important tools that will enlarge and improve the teacher's effort in teacher mediation to support, scaffold, and promote the occurrence of student's EP in the classroom. The structured use of VR can support students in important aspects of their inquiry, including knowledge articulation, testing, communication, and refinement (Sandoval et al., 2000). In that sense, VR are mediators (Ares, Stroup, \& Schademan, 2009; Vygotsky, 1978), i.e., artefacts and whatever their degree of abstraction and support, with which students can manipulate to generate their understandings about scientific knowledge and practice. Manipulable mediators (Kelly \& Duschl, 2002) allow students to have a dynamic of interaction with epistemic objects to develop important epistemic skills (Carrara, Cherubini, \& Giaretta, 2006). This interaction is part of the axiological epistemic dimension of mediation (Lopes et al., 2010) mainly related with the interaction with epistemic objects. The manipulable mediators (MM) need to be artefacts (Magnani, 2004; Nordmann, 2007) and are more effective if workable and manageable (Knuuttila, 2005). As MM we can have objects, manageable models (physical, virtual, or based on new technology), computer simulations, devices, and VR, independent of medium and degree of abstraction with which students can interact to allow conciseness and understanding according to students' prior 
knowledge. VR can be a MM whether it can be created, manipulated, and refined by students to organise information, conceptualise a situation, and represent a relationship between variables, and so on.

VR potentiate also the dynamics of teacher mediation related with interaction with "the others" (Lopes et al., 2010) through discursive practices (verbal or not verbal), when they are used to inform, to communicate, to illustrate an idea (Brooks, 2009), or to motivate and engage students. VR also work as illustrations when they are used with semiotic functions (Jaipal, 2010; Lemke, 1998; Mariotti, 2000).

The use of several forms of VR, as MM, by teachers and students facilitates students' interaction with epistemic objects (Magnani \& Dossena, 2005), making them operational, and they have positive effects on students' EP, increasing their occurrence. The use of VR can also have positive effects on the progress of EP from observations and data, to closer to theoretical constructs (Jiménez-Aleixandre \& Reigosa, 2006). This involves a progressive meaning-making process, where students learn how scientific theories relate to real-world phenomena (Driver, Leach, Millar, \& Scott, 1996). During this progressive meaning-making process, students need to learn how to connect concepts to the context, and this requires the students' involvement in EP to coordinate data with theory, representing and transforming data or reacting to anomalous data (Jiménez-Aleixandre \& Reigosa, 2006).

This study intends to highlight the role of VR on the promotion and development of students' EP, and also to know what triggers the use of VR in the physical science classrooms, in particular teacher actions that can foster or enable its use. Through actions and languages (Lopes, Cravino, Branco, Saraiva, \& Silva, 2008a) teachers can scaffold and promote the students' EP (McNeill \& Krajcik, 2009) and help them connect theories, practices, and explanations of phenomena (Sandoval \& Reiser, 2004). The emergence of a theoretical framework incorporating the semiotic and epistemic functions (Jaipal, 2010) of VR on the improvement of students' understanding of scientific phenomena has the potential to inform teachers' mediation practices, helping them to achieve a better understanding about how to maximise learning opportunities through a student's epistemic work with VR (Hubber, Tytler, \& Haslam, 2010).

The research questions of this study are: (a) how can teachers trigger the use of VR by students in classroom? (b) What functions can be attributed to VR in physical sciences classrooms? (c) What is the impact of VR on students' EP? In all these questions the dependence on the context and teacher experience will be analysed.

\section{Methodology of Research}

This is a research work with a qualitative nature, which consists of a multicase study (Cohen, Manion, \& Morrison, 2000) involving five physical sciences teachers from secondary school (students age 13-15 years) with different teaching experience, academic degrees, and practice in research in the field of physical sciences education. The research methods adopted were the content analysis (Krippendorf, 2004) of nine multimodal narratives from the lessons taught by five case study teachers from different public schools from Portugal, all about the disciplinary subjects of Physics and Chemistry $\left(7^{\text {th }}, 8^{\text {th }}\right.$, and $9^{\text {th }}$ grades $)$. The results of the content analysis are submitted to cluster analysis (Krippendorf, 2004; Lopes et al., 2008b) in order to identify patterns for teacher mediation dynamics concerning the use of VR that are determinant in the promotion of students' EP. 
PROBLEMS

OF EDUCATION

IN THE $21^{\text {st }}$ CENTURY

Volume 42, 2012

100

\section{Characteristics of Case Studies}

For the present work, in order to study the role played by the VR (as MM) in the development of the student EP in the classroom, we analysed nine multimodal narratives from five secondary school teachers, which correspond to our five case studies. The teachers have different characteristics in terms of professional experience (combining the time teaching and the experience in research in science education field). The dynamics of teacher mediation were studied, taking into account the way they are introduced (as manipulable mediator or illustration of visual representation of the referent) and used in the context of the task proposed to the students or during the work developed by them in the classroom.

The five teachers selected as our five case studies taught physical sciences in five different public schools in Portugal. The main characteristics and background information about our five case studies for this qualitative research are presented in Table 1.

Table 1. Main characteristics of the five case studies.

\begin{tabular}{|c|c|c|c|c|c|}
\hline Teacher & A & B & C & D & E \\
\hline Gender & Female & Female & Male & Female & Female \\
\hline $\begin{array}{l}\text { Academic } \\
\text { degree }\end{array}$ & $\begin{array}{l}\text { PhD student of } \\
\text { Physical Sci- } \\
\text { ences Education }\end{array}$ & $\begin{array}{l}\text { PhD student of } \\
\text { Physical Sciences } \\
\text { Education }\end{array}$ & $\begin{array}{c}\text { Licensee in } \\
\text { Physics and } \\
\text { Chemistry } \\
\text { teaching }\end{array}$ & $\begin{array}{c}\text { Licensee in } \\
\text { Physics and } \\
\text { Chemistry } \\
\text { teaching }\end{array}$ & $\begin{array}{c}\text { PhD student } \\
\text { of Physical } \\
\text { Sciences } \\
\text { Education }\end{array}$ \\
\hline $\begin{array}{l}\text { Teaching expe- } \\
\text { rience }\end{array}$ & 28 years & 15 years & 15 years & 15 years & 23 years \\
\hline $\begin{array}{l}\text { Research } \\
\text { experience }\end{array}$ & Yes & Yes & No & No & Yes \\
\hline $\begin{array}{l}\text { Grade and } \\
\text { topic of the les- } \\
\text { sons analysed }\end{array}$ & $\begin{array}{c}\text { Physics } \\
9^{\text {th }} \text { grade } \\
\text { Electrical Circuits }\end{array}$ & $\begin{array}{c}\text { Chemistry } \\
8^{\text {th }} \text { grade } \\
\text { Chemical Reac- } \\
\text { tions }\end{array}$ & $\begin{array}{l}\text { Physics } \\
7^{\text {th }} \text { grade } \\
\text { Energy }\end{array}$ & $\begin{array}{l}\text { Physics } \\
8^{\text {th }} \text { grade } \\
\text { Optics }\end{array}$ & $\begin{array}{l}\text { Chemistry } \\
8^{\text {th }} \text { grade } \\
\text { Chemical } \\
\text { Bonding }\end{array}$ \\
\hline Inquiry context & Yes & Yes & Yes & Yes & Yes \\
\hline $\begin{array}{l}\text { No. of students } \\
\text { in the lessons } \\
\text { analysed }\end{array}$ & 19 & 22 & 23 & 29 & 26 \\
\hline
\end{tabular}

The teachers were selected on the basis of their differences in terms of teaching experience defined as the mix of time teaching and experience in research in science education. So, in terms of professional development, we can consider the teachers A and D as the more experienced, and teachers $\mathrm{C}$ and $\mathrm{D}$ as the less experienced. Teacher $\mathrm{B}$ is in the middle of the two groups because she has almost the same years of teaching as teachers $C$ and $D$, but has higher academic studies and has some experience in research in the field of physical sciences education.

\section{Multimodal Narratives}

The focus of this work is the study of teacher mediation; in particular the role played by VR on the promotion of student EP in the classroom. Since the teacher plays a central role, we elect him as central actor capturing his intention and preserving the complex and holistic 
Elisa SARAIVA, J. BERNARDINO LOPES, J. PAULO CRAVINO, Carla A. SANTOS. How do Teachers of Physical Sciences with Different Professional Experiences Use Visual Representations with Epistemic Functions in the Classroom

nature of teaching and learning. For that, following the same approach adopted by Santos,
OF EDUCATION
IN THE $21^{\text {st }}$ CENTURY
Volume 42, 2012

Lopes, and Cravino (2011), multimodal narratives were used as the central component of a hermeneutic unit that encompasses all types of data collected inside and outside the classroom. They include multimodal elements such as schemas of spatial organisation of the classroom, schemes put on the blackboard by the teacher and/or by students, student reactions, explicit teacher's intentions and decisions, photocopies of students' notebook, teacher's documents, photos of the equipment used, and indication of silences and gestures, amongst others. The multimodal narratives correspond to the act of narrating, as descriptive as possible, relevant episodes of teacher mediation (Lopes et al., 2010) based on audio recording of the lesson, several documents, and multimodal elements obtained by the teacher. All multimodal narratives have the same structure, which allows comparability. The first part of the multimodal narrative is a general description of the lesson and its contextual elements. The second part is a detailed description of what happens during each episode, which begins with the presentation of a task and finishes with the beginning of another task (Lopes et al., 2010).

The multimodal narratives analysed correspond to the nine lessons taught by the five case study teachers. Two multimodal narratives were analysed for each teacher, with the exception of teacher $\mathrm{E}$ (one multimodal narrative analysed).

The multimodal narratives were constructed by the teachers themselves (cases A, B) or by a researcher from our team (cases C, D, and E) that, without attending the lessons, constructed the narratives based on the elements provided by the teachers (audio recordings, reports, teachers and pupils' daily notes, documents, photos, etc.) and appropriate interactions with the teacher after the lessons. All the multimodal narratives have the same focus (the tasks proposed to students and what teacher and students did with those tasks) and the same structure to allow us to compare different narratives, done by different teachers.

The content of the lessons that correspond to the multimodal narratives analysed have the main characteristics presented in Table 2. 
PROBLEMS

OF EDUCATION

IN THE $21^{\text {st }}$ CENTURY

Volume 42,2012

102

\section{Table 2. Main characteristics of the lessons on the basis of the nine narrations of teacher mediation.}

\begin{tabular}{|c|c|}
\hline Teacher & Brief description of the tasks proposed \\
\hline $\begin{array}{l}\text { Teacher A } 1^{\text {st }} \\
\text { Lesson } \\
(45 \mathrm{~min})\end{array}$ & $\begin{array}{l}\text { Teacher starts with a synthesis of previous lesson. Delivers to each group a worksheet with two } \\
\text { images of an electrical installation. The working group was guided by issues raised in the worksheet. } \\
\text { The answers to each question were discussed and students made some conclusions. }\end{array}$ \\
\hline $\begin{array}{l}\text { Teacher A } \\
2^{\text {nd }} \text { Lesson } \\
(90 \text { min })\end{array}$ & $\begin{array}{l}\text { A group of students construct an electrical circuit and make measurements of physical quantities } \\
\text { placing the values in a table. Teacher helps students build a graph to relate the intensity of electric } \\
\text { current with the potential difference, and made some conclusions about Ohm's Law. }\end{array}$ \\
\hline $\begin{array}{l}\text { Teacher B } \\
1^{\text {st }} \text { Lesson } \\
\text { (90 min) }\end{array}$ & $\begin{array}{l}\text { Students observe an image with dead fish floating in a lake and answer questions about the phe- } \\
\text { nomenon of acid rain. Students do the neutralisation of a solution of sodium hydroxide, by the action } \\
\text { of the } \mathrm{CO}_{2} \text { released when they talk into the flask. The } 3^{\text {rd }} \text { task was the determination of pH value of } \\
\text { three acid solutions and the registration of values on a table. }\end{array}$ \\
\hline $\begin{array}{l}\text { Teacher B } \\
2^{\text {nd }} \text { Lesson } \\
(90 \text { min })\end{array}$ & $\begin{array}{l}\text { Teacher distributes a picture of the water cycle and sources of pollution. Students have to identify } \\
\text { those who cause the acidity in the rain and write the respective chemical equations. Then they were } \\
\text { presented a map of Portugal with different areas of water hardness. Students relate it with the forma- } \\
\text { tion of stalactites and stalagmites. The students' work includes representation, handling, observation, } \\
\text { interpretation, and explanation of facts and events. }\end{array}$ \\
\hline $\begin{array}{l}\text { Teacher C } \\
1^{\text {st }} \text { Lesson } \\
(90 \mathrm{~min})\end{array}$ & $\begin{array}{l}\text { Teacher starts talking about energy and defines the concepts: system, energy source, and energy } \\
\text { transference. He presents a label from a box of breakfast cereals with the intention to lead students } \\
\text { to establish the relationship between units Calorie and Joule. However, he doesn't allow students } \\
\text { autonomous work. }\end{array}$ \\
\hline $\begin{array}{l}\text { Teacher C } \\
2^{\text {nd }} \text { Lesson } \\
(90 \mathrm{~min})\end{array}$ & $\begin{array}{l}\text { Teacher uses a Powerpoint presentation with examples of renewable and non-renewable sources } \\
\text { of energy. He informs students about the advantages and disadvantages of each. Teacher uses the } \\
\text { software Modellus (Teodoro, Vieira, \& Clérigo, 2000) to establish relationships between energy forms } \\
\text { (kinetic and potential) and the variables that change it. }\end{array}$ \\
\hline $\begin{array}{l}\text { Teacher D } \\
1^{\text {st }} \text { Lesson } \\
\text { (90 } \mathrm{min})\end{array}$ & $\begin{array}{l}\text { Teacher writes the concepts of luminary and illuminated bodies on the blackboard. Asks questions } \\
\text { about rectilinear propagation of light. She made a demonstration with a candle. Students are called } \\
\text { to identify the transparent, translucent, and opaque objects. Asks about the shadow formation. She } \\
\text { makes a sketch of a solar eclipse on the blackboard. Students do a summary about the electromag- } \\
\text { netic spectrum. }\end{array}$ \\
\hline $\begin{array}{l}\text { Teacher D } \\
2^{\text {nd }} \text { Lesson } \\
(45 \text { min })\end{array}$ & $\begin{array}{l}\text { Teacher starts with some explanations about the reflection laws, and writes them on the blackboard. } \\
\text { She uses also a scheme. She made some demonstrations with the optic kit (lamp, a semicircle, } \\
\text { and a slot). Then asks about different kinds of mirrors and shows different mirrors. She summarises } \\
\text { about the characteristics of images obtained with each one and presents some applications of each } \\
\text { kind of mirror. }\end{array}$ \\
\hline $\begin{array}{l}\text { Teacher } E \\
1^{\text {st }} \text { Lesson } \\
(45 \mathrm{~min})\end{array}$ & $\begin{array}{l}\text { Teacher starts by questioning the students about corpuscular nature of matter. She presents to the } \\
\text { students some atomic models. Then she invites students to construct some molecular models and } \\
\text { scaffolds the students' work with questions. }\end{array}$ \\
\hline
\end{tabular}

\section{Data Analysis}

The process of data analysis of the nine multimodal narratives was done in several steps by different researchers, based on content analysis (Krippendorf, 2004) and using the coding capacities of NVivo $8^{\circledR}$. The analysis in all steps was made by one researcher of our team who identified and coded the parts of the multimodal narratives that contain evidence about the use 
Elisa SARAIVA, J. BERNARDINO LOPES, J. PAULO CRAVINO, Carla A. SANTOS. How do Teachers of Physical Sciences with Different Professional Experiences Use Visual Representations with Epistemic Functions in the Classroom

of visual representation (by students and teachers), about the students' EP that take place in the classroom and about the teacher actions, concerning the use of VR (both as manipulable mediator or as illustration) that promote or enable such EP. Then, the multimodal narratives were analysed by another two researchers in order to validate the process. This procedure allows us to express the results with a higher level of reliability.

The steps of first order data analysis, which was data driven, were the following:

- Select and code all passages from multimodal narratives that contain evidence about the use of VR in the classroom, identifying when they were used as MM or as illustration. It was also identified if the VR (used both as manipulable mediator or illustration) were introduced and used by the teacher or by students.

- Identify and code the parts of the multimodal narratives that contain evidences about the occurrence of students' EP. The criteria used to recognise this occurrence was the identification of students' investigative actions in order to solve a problem or answer a question (Sandoval, 2005).

- Select and code the parts of the multimodal narratives related to the teachers' actions and languages adopted to promote, develop, enlarge, or inhibit the students' EP (spontaneous or induced by teacher).

All the parts of the multimodal narratives were coded and reviewed by another researcher to determine whether all evidence about the teacher actions and students' EP that take place, related or not with the use of VR, were covered. If not, improvements were made. Each category was given a name and a brief description (see Tables 3 and 4). All multimodal narratives were reanalysed by other researchers, using also NVivo $8^{\circledR}$, to get an effective verification using the same criteria for evidence. In this verification, $95 \%$ of agreement was obtained in categorisations made by different researchers. When there were divergences in the data analysis process, the researchers involved discussed and reflected together in order to achieve consensus about the emergent categories.

The second order analysis, guided by research questions, allows the identification of teacher actions that trigger the use of VR (either as illustration or as manipulable mediator) and also are determinant for the occurrence and enlargement of students' EP. The episode was used as a unit of analysis (what happens during the accomplishment of a task).

All episodes were organised in diagrams (Figure 1) based on the previous categorisation process. The relationships between the successive teacher actions and the student's EP that take place become clear. The circles contain the identification of the student's EP that takes place. The arrows indicate the direction of each action.

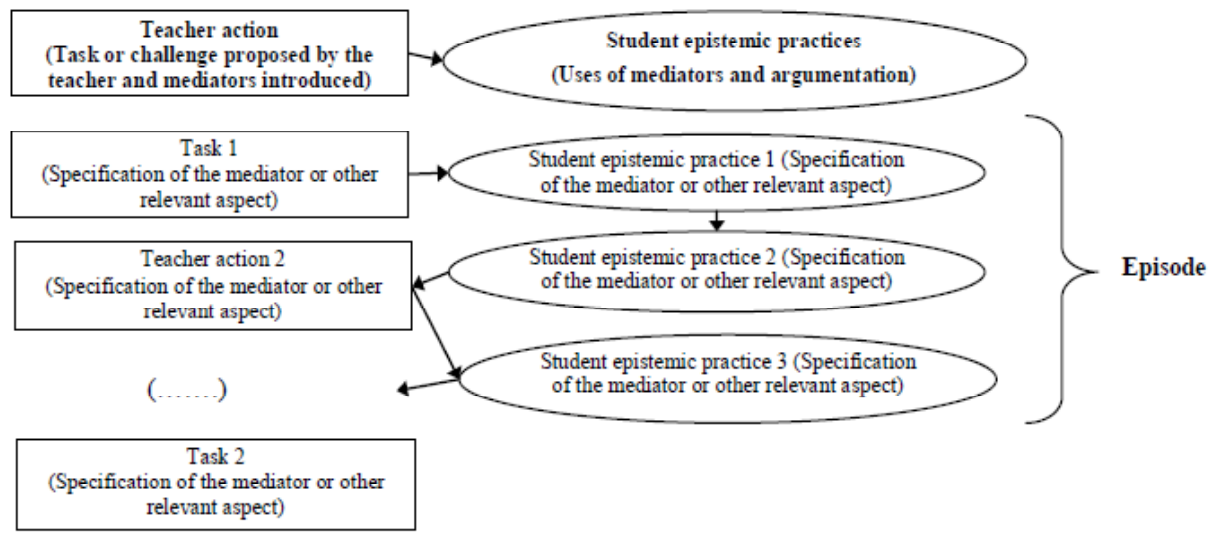
Figure 1: Scheme representing successions of teacher actions and students' EPs
during an episode. 
PROBLEMS

OF EDUCATION

IN THE $21^{\text {st }}$ CENTURY

Volume 42, 2012

104

The data collected in the first order analysis was used for construction of a matrix for all five case study teachers. To construct the matrix of cases, the variables adopted were about a teacher's actions and students' EP related or not to the use of VR, both as manipulable mediator or illustration. For each case and all the variables the respective presence (value "1") or absence (value "0") of the category was quantified, and the respective matrix constructed. The matrix was submitted to cluster analysis (Krippendorf, 2004; Lopes et al., 2008b) using the software Statistica and the results were displayed using linkage tree-like diagrams (Figure 3 ). We adopted the "Ward's method" for data arrangement and the "percent disagreement" as calculation method for the distance between cases (Kaufman \& Rousseeuw, 1990).

\section{Results of Research}

\section{What Triggers the Use of Visual Representations (VR) in the Classroom}

From the analysis of multimodal narratives it was identified (Figure 2) that: (a) all teachers introduce VR in lessons [the most experienced teachers (A, B, E) introduce a smaller number of VR per lesson]; (b) only the teachers most experienced (A, B, E) allow their students to introduce and use their own VR [only in the case of teacher B; the VR introduced by the students are used by the teacher]; (c) only in lessons of experienced teachers were all VR used. Besides, each VR was used more than one time during the task development, only in lessons of most experienced teachers (A, B, E), [especially in the case of teachers A and E; the use of each visual representation was intensive]. The less experienced teachers (C and D) introduce the VR, but most of the time they are responsible for its use in the classroom, and they do not request any action from their students in order to make them use the VR as mediator (either as illustration or as manipulable mediator).

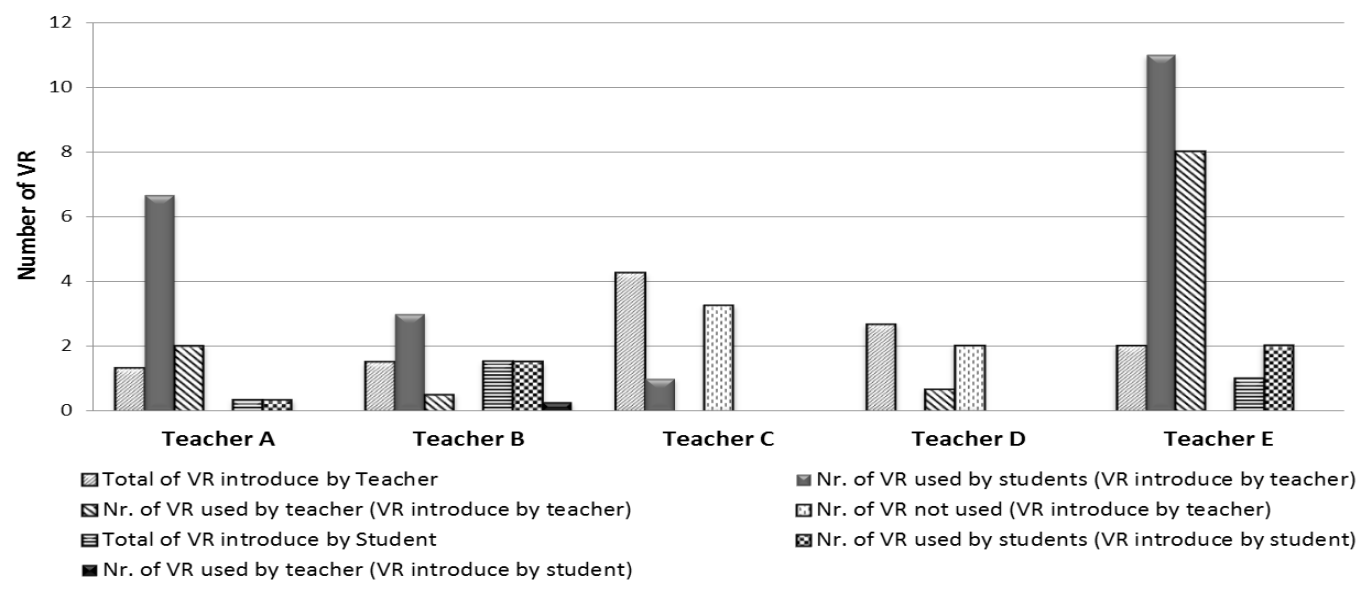

\section{Figure 2: Students and teachers use of VR in the classroom per period of time of $45 \mathrm{~min}$.}

Some parts extracted from the multimodal narratives are given as examples about how teachers and students introduce and use VR in the classroom:

Example of VR introduced by students and used by students (from MN teacher A): [...] Students represent schematically, on the notebook, the electrical circuit that they are watching. [...] 
Elisa SARAIVA, J. BERNARDINO LOPES, J. PAULO CRAVINO, Carla A. SANTOS. How do Teachers of Physical Sciences with Different Professional Experiences Use Visual Representations with Epistemic Functions in the Classroom

Example of VR introduced by teacher and used by students (from MN teacher E): [...] Using another atomic model, teacher continues questioning students in order to identify whether it is a molecule or an atom. Teacher uses the models of hydrogen and chlorine molecules. Teacher refers to chemical bonding between atoms and asks students about the number of atoms that exist in each model presented. Students always respond correctly.

Teacher - This one, is it an atom or a molecule?

Student - Molecule. It has two atoms.

Teacher - Have two atoms linked together chemically (the teacher agrees). Therefore it is a molecule...?

Student - Of hydrogen. [...]

Example of VR introduced by the teacher and used by the teacher (from MN teacher C): [...] The teacher chooses on the Modellus simulation only two levels and changes colors to identify the resulting graph of the curve of kinetic energy and potential energy and explains: What I have here is what happens with kinetic and potential energy. There is a transformation of this potential energy into kinetic energy. I have here a basquet ball, this one (pointing to simulation), which is a certain height from the floor. I considered 45 meters. [...]

Example of VR introduced by student and used by the teacher (from MN teacher B): [...] I read what students wrote:
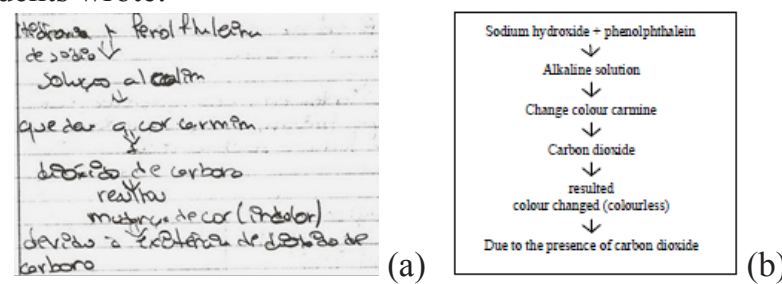

(Word scheme to represent the chemical reaction and it's translation (students group V);

- You have everything there: the reactants, products, observations ... everything is there. Try to arrange this. You get the idea? It changed color.... why? - I tried. [...]

\section{Functions Attributed to VR}

As referred above, the most experienced teachers (teachers A, B, and E) use a smaller number of VR in the classroom. However, from the analysis of multimodal narratives (Figure 3 ) in the lessons of these teachers, the VR were used predominantly as manipulable mediator (MM). Teacher A only uses VR as MM.

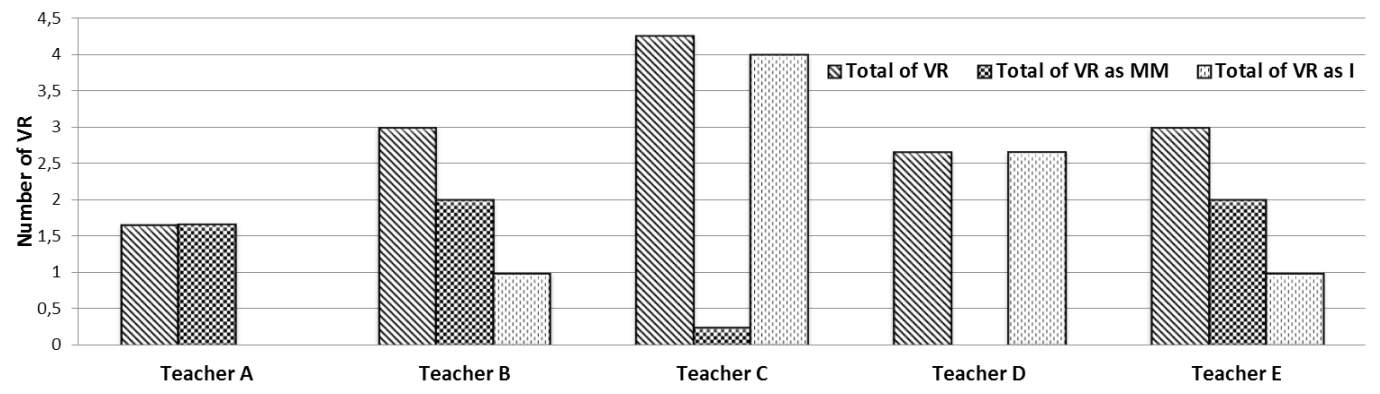

Figure 3: VR used as manipulable mediator (MM) or as illustration (I) per period of time of $\mathbf{4 5} \mathrm{min}$. 
PROBLEMS

OF EDUCATION

IN THE $21^{\text {st }}$ CENTURY

Volume 42,2012

106

In particular, teacher A only uses VR as MM. Teacher C introduces a large number of VR in the classroom, but mainly as illustration. Teacher D only introduces VR as illustration.

As examples about the use of VR as mediators, some brief excerpts from multimodal narratives are presented in the following:

VR introduced as illustration: [...] Teacher shows an image with dead fish floating in a lake and students answer questions about the phenomenon of acid rain.

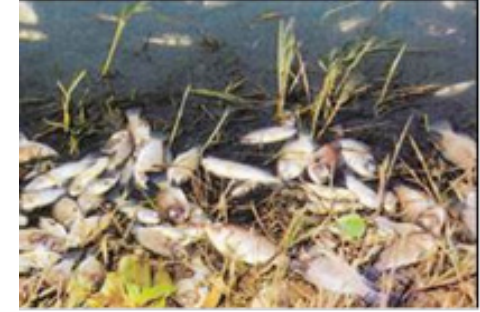

VR used as illustration: [...] Based upon a chart about use of energy sources, students need to answer the question: What is the percentage of renewable energy used worldwide?

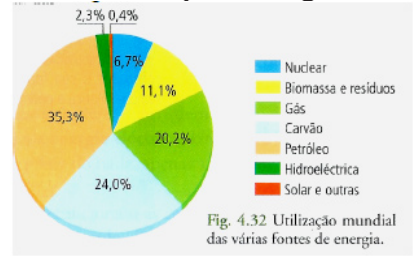

VR introduced as manipulable mediator: [...] After students said that they don't have any doubts, teacher asks students to build molecular models of molecules whose chemical formulas she has written on the blackboard. [...]

\section{VR used as manipulable mediator:}

$[\ldots]$

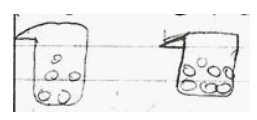

(Drawing made by students about the particles in the solution as they imagined it)

Then I questioned the students about the particles and how they imagine them:

- These here are in the gaseous state.... - Catarina says.

- Gas?! Do you have any particle in the gaseous state? - I said.

- Liquid state! - corrects the student. [...]

\section{Relationships among Teacher's Effort, Students' Epistemic Practices, and Type of Use of VR}

In order to identify the relationship between the use of VR both as MM or as illustration, and the occurrence of students' EP, the multimodal narrations were analysed with the identified categories about the students' EP that take place associated or not with the use of VR, both as MM or illustration.

During teachers A, B, and E lessons, the number of evidences about the occurrence of students' EP was bigger (Figure 4). As Figure 4 shows, only in the most experienced teachers (A, B, and E) students' EP are associated with the use of VR, as MM or illustration. Also, only in the most experienced teachers (A, B, and E) the of students' $\mathrm{EP}$ are associated with the use of VR as MM. During teachers B and E lessons there are many evidences about the occurrence of students' EP related with the use of VR as illustration. Confronting the results presented in 
Elisa SARAIVA, J. BERNARDINO LOPES, J. PAULO CRAVINO, Carla A. SANTOS. How do Teachers of Physical Sciences with Different Professional Experiences Use Visual Representations with Epistemic Functions in the Classroom

Figure 3 and Figure 4, it is possible to verify that most of VR used by teachers C and D do not

have any epistemic function, that is, VR associated with EP.

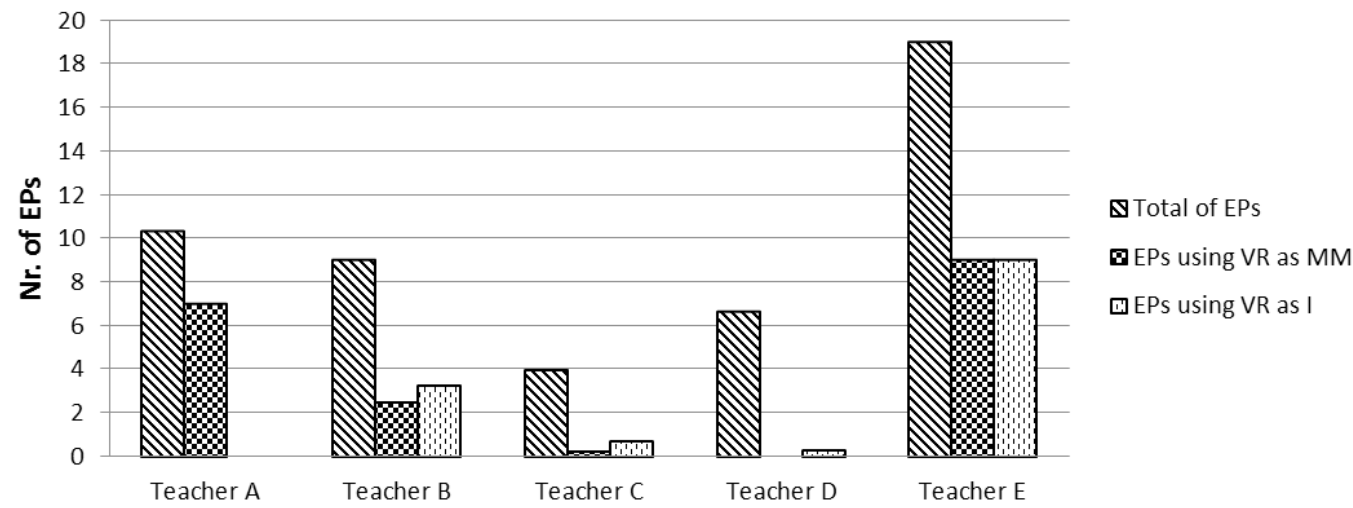

\section{Figure 4: Students' EPs using VR as manipulable mediator (MM) or as illustra- tion (I) per period of time of $\mathbf{4 5} \mathrm{min}$.}

The emergent categories for students' EP described in Table 3 are the ones identified in the multimodal narratives analysed.

\section{Table 3: Emergent categories for students' epistemic practices (EP).}

\begin{tabular}{|c|c|}
\hline Epistemic Practice & Description \\
\hline Observe (0) & $\begin{array}{l}\text { The students, either per se or supervised by teacher, observe and describe objects, } \\
\text { images, schemas, experimental assembly, etc. }\end{array}$ \\
\hline $\begin{array}{l}\text { Present mobilising idea } \\
\text { (PMI) }\end{array}$ & $\begin{array}{l}\text { The students, either per se or supervised by teacher, mobilise prior knowledge to guide } \\
\text { a possible way to solve the problem. }\end{array}$ \\
\hline $\begin{array}{l}\text { Identify empirical condi- } \\
\text { tions (IEC) }\end{array}$ & $\begin{array}{l}\text { The students, either per se or supervised by teacher, identify the empirical conditions of } \\
\text { a physical situation in which the phenomenon (a) occurs. }\end{array}$ \\
\hline $\begin{array}{l}\text { Handle equipment factu- } \\
\text { ally (HEF) }\end{array}$ & $\begin{array}{l}\text { The students, either per se or supervised by teacher, handle equipment following } \\
\text { instructions given by teacher, or tentatively without any guiding knowledge. }\end{array}$ \\
\hline Question factually (QF) & $\begin{array}{l}\text { The students, either per se or supervised by teacher, ask questions to clarify terms or } \\
\text { observations related to empirical conditions of a phenomenon. }\end{array}$ \\
\hline Organise information (OI) & $\begin{array}{l}\text { The students, either per se or supervised by teacher, register, classify, or structure the } \\
\text { data collection. }\end{array}$ \\
\hline $\begin{array}{l}\text { Communicate non autono- } \\
\text { mously (CNA) }\end{array}$ & $\begin{array}{l}\text { The students present their ideas, or results, strongly related with the teacher sugges- } \\
\text { tions or requests. }\end{array}$ \\
\hline Interpret (I) & $\begin{array}{l}\text { The students, either per se or supervised by teacher, interpret images, diagrams, } \\
\text { objects, partial data, etc. }\end{array}$ \\
\hline Establish relations (ER) & $\begin{array}{l}\text { The students, either per se or supervised by teacher, establish relations between data } \\
\text { variables and/or concepts in different situations. }\end{array}$ \\
\hline $\begin{array}{l}\text { Question conceptually } \\
\text { (QC) }\end{array}$ & $\begin{array}{l}\text { The students, either per se or supervised by teacher, formulate questions and problems } \\
\text { based on knowledge to obtain new understanding of phenomenon, concepts, models. }\end{array}$ \\
\hline Conceptualise (C) & $\begin{array}{l}\text { The students, either per se or supervised by teacher, make a symbolic representation } \\
\text { of a phenomenon. }\end{array}$ \\
\hline $\begin{array}{l}\text { Change representation } \\
\text { format (CRF) }\end{array}$ & $\begin{array}{l}\text { The students, either per se or supervised by teacher, change the symbolic representa- } \\
\text { tion to another. }\end{array}$ \\
\hline Evaluate critically (EC) & $\begin{array}{l}\text { The students, either per se or supervised by teacher, analyse and argue, making critical } \\
\text { evaluation of hypothesis, resources, results, used language, etc. }\end{array}$ \\
\hline $\begin{array}{l}\text { Communicate autono- } \\
\text { mously (CA) }\end{array}$ & $\begin{array}{l}\text { The students, either per se or supervised by teacher, present their ideas, results, or } \\
\text { conclusions about their epistemic work. }\end{array}$ \\
\hline
\end{tabular}


PROBLEMS

OF EDUCATION

IN THE $21^{\text {st }}$ CENTURY Volume 42, 2012

108

The categories that emerge from the analysis of the multimodal narratives about the teacher's mediation actions that enlarge or decrease the student's opportunities for developing EP are presented and briefly defined in Table 4.

The action of present task as challenge (TC) is associated with a large number of a student's EP. Other teacher actions, such as a request for additional aspects (RAA), valorise epistemically (VE) the students' work and make explicit epistemically (EE) the statute of the work done or ongoing. They also positively impact the development of students' EP. Such actions are more frequent (were found more evidences in $\mathrm{MN}$ ) during the lessons of teachers A, B, and E (see Table 5).

When the task is absent or inadequate (AIT) in epistemic terms, there are fewer students' EP. Also, the actions short-circuit (SC) the students' work (i.e., teacher doesn't allow the students the opportunity to accomplish the task by themselves), ignore epistemically (I) the students' ideas, as well as devaluate epistemically (DE). And the dispersion on the approach (DA) of situations can enable the occurrence of students' EP. Such actions are very frequent (in terms of evidences found in $\mathrm{MN}$ ) during teachers' $\mathrm{C}$ and $\mathrm{D}$ lessons (see Table 5 and Figure 5). That is, there are, in the classrooms of these teachers, many episodes that mean several tasks for students and less time to accomplish each one.

Table 4. Emergent categories for teacher's mediation actions.

\begin{tabular}{|l|l|}
\hline $\begin{array}{c}\text { Teacher's actions that decrease or } \\
\text { enhance students' opportunities } \\
\text { for EP }\end{array}$ & \\
\hline Short-circuit (SC) & $\begin{array}{l}\text { Teacher proposes a task with potential to develop student's EP. How- } \\
\text { ever, teacher doesn't allow students the opportunity to accomplish, by } \\
\text { themselves, the task. Sometimes students are only invited to realise the } \\
\text { mechanic aspects of the task. }\end{array}$ \\
\hline Ignore epistemically (I) & $\begin{array}{l}\text { Teacher ignores the students' ideas, questions, or the initiatives to develop } \\
\text { EP. }\end{array}$ \\
\hline Devaluate epistemically (DE) & $\begin{array}{l}\text { The teacher expresses his epistemic conception, devaluing a potential } \\
\text { epistemic practice by the student. }\end{array}$ \\
\hline Dispersion on the approach (DA) & The teacher doesn't focus on a manageable number of situations. \\
\hline Absent or inadequate task for EP (AIT) & $\begin{array}{l}\text { There is an implicit task (e.g., request students' attention to approach a new } \\
\text { subject) or there is an explicit request for some kind of activity that does not need } \\
\text { epistemic practice. }\end{array}$ \\
\hline Present task challenge (TC) & Teacher proposes a task as a challenge. \\
\hline Synthesise (S) & Teacher takes student's EP to reinforce their understanding. \\
\hline Request additional aspects (RAA) & Teacher requests additional aspects to students to clarify the EP. \\
\hline Introduce manipulable mediator & $\begin{array}{l}\text { Teacher introduces an artefact workable by students (e.g., visual represen- } \\
\text { tation; computer simulation). }\end{array}$ \\
\hline Use manipulable mediator & $\begin{array}{l}\text { Teachers use (or show how to use) a manipulable mediator to improve the } \\
\text { students' understanding. }\end{array}$ \\
\hline Extend (E) & $\begin{array}{l}\text { Teacher requests additional aspects to students' answers to extend or } \\
\text { consider new perspectives. }\end{array}$ \\
\hline Valorise epistemically (VE) & $\begin{array}{l}\text { Teacher uses ideas, schemes, or actions of students recognising epistemic } \\
\text { value (e.g., hypothesis, predictions, etc.). }\end{array}$ \\
\hline Make explicit epistemically (EE) & Teacher makes explicit the epistemic statute of the work done or ongoing. \\
\hline
\end{tabular}


Elisa SARAIVA, J. BERNARDINO LOPES, J. PAULO CRAVINO, Carla A. SANTOS. How do Teachers of Physical Sciences with Different Professional Experiences Use Visual Representations with Epistemic Functions in the Classroom

From the cluster analysis, we can identify patterns for teacher mediation dynamics concerning the use of VR that are determinant in the promotion of students' EP. In the dendogram for all cases (Figure 5), there are two big groups: the group where VR are used as manipulable mediators (MM group) and the group where VR are used as illustration (I group).

The MM group is composed of teacher A (episodes C_2 to C_5), teacher B (episodes C_7 to $C_{-} 9$ and $C_{-} 11$ ), and teacher E (episodes C_35). The I group is composed of teacher C (episodes C_12 to C_27), teacher D (episodes C_28 to C_34), teacher A (episode C_1), and teacher $B$ (episode $C_{-} 6$ ). Teacher $E$ (episode $C_{-}$36) has a different pattern for use of VR as illustration (see Table 5).

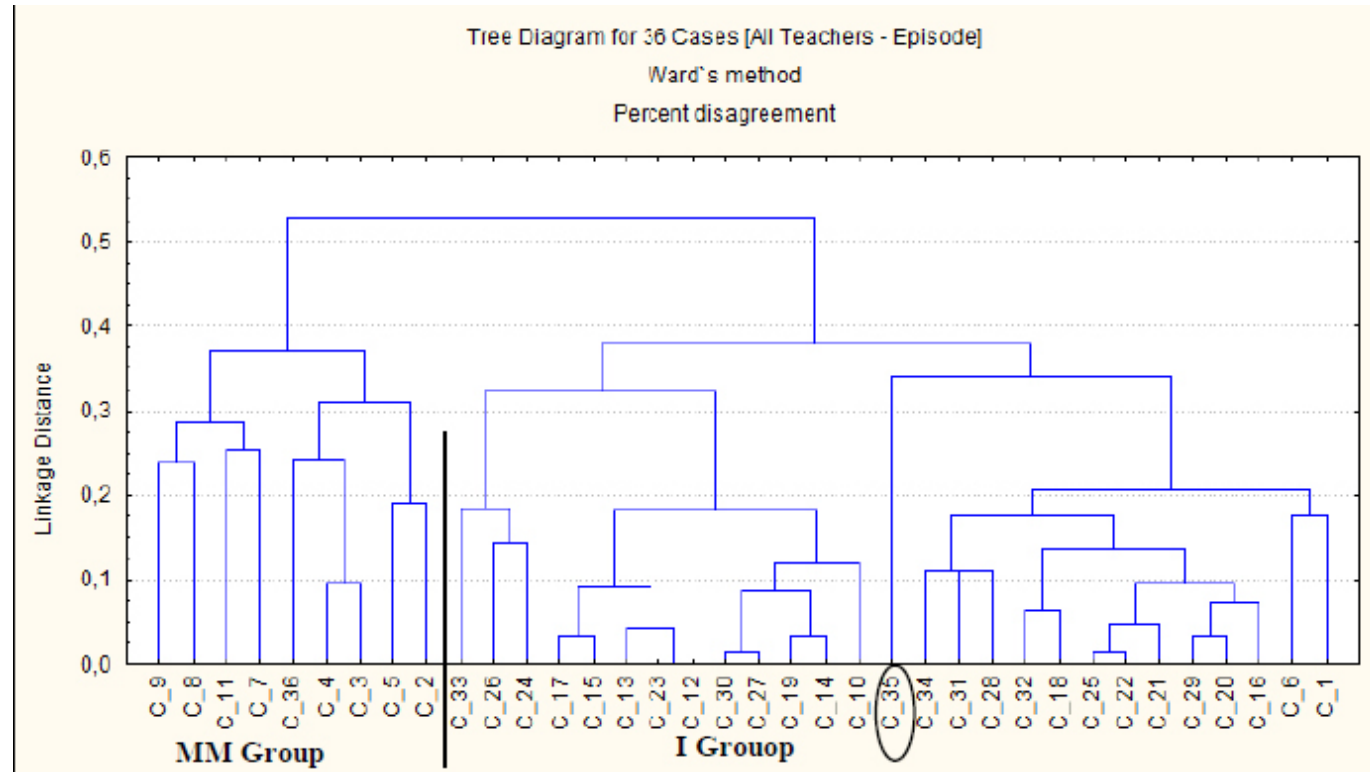

Figure 5: Dendogram for all teachers' episodes.

For each group in the dendogram (Figure 5), were also identified three patterns of teachers' mediation actions (Table 5), which are determinant for the occurrence of students' EP. 
PROBLEMS

OF EDUCATION

IN THE $21^{\text {st }}$ CENTURY

Volume 42, 2012

110

\section{Table 5. Patterns of use of VR identified in cluster analysis.}

\begin{tabular}{|c|c|c|}
\hline $\begin{array}{c}\text { Patterns of use } \\
\text { of VR }\end{array}$ & More frequent teacher mediation actions & $\begin{array}{c}\text { More frequent students } \\
\text { EP }\end{array}$ \\
\hline $\begin{array}{l}\text { MM Group: VR } \\
\text { used as manipula- } \\
\text { ble mediators (MM) } \\
\text { either in teacher's } \\
\text { actions or students' } \\
\text { practices. } \\
\text { (Teachers A, B, } \\
\text { and E) }\end{array}$ & $\begin{array}{l}\text { - Teacher proposes a task as challenge, with the intro- } \\
\text { duction of VR as MM (Teachers A, B, and E); } \\
-\quad \text { Teachers' actions using VR as MM: synthesise } \\
\text { (Teacher B) and request additional aspects (Teacher A); } \\
\text { - Teachers' actions without using VR as MM: requests } \\
\text { additional aspects (Teacher B); valorise epistemically (Teach- } \\
\text { ers A and E) and make explicit the epistemic statue of students' } \\
\text { work (Teacher B). }\end{array}$ & $\begin{array}{l}\text { - EP with use of VR as } \\
\text { MM: observe; interpret; } \\
\text { establish relations; } \\
\text { handle equipment factu- } \\
\text { ally; question factually; } \\
\text { conceptualise. }\end{array}$ \\
\hline $\begin{array}{l}\text { I Group: VR intro- } \\
\text { duced as illustration } \\
\text { by teachers. } \\
\text { (Teachers B, C, } \\
\text { and D) }\end{array}$ & $\begin{array}{l}\text { - Absent or inadequate task for EP with the introduction } \\
\text { of VR as illustration (Teachers B, C, and D); } \\
-\quad \text { Dispersion on the approach of physical situations } \\
\text { (Teacher C); } \\
-\quad \text { Teacher ignores epistemically the students' actions } \\
\text { (Teachers C and D); } \\
-\quad \text { Teacher proposes a task as challenge (Teachers B, } \\
\text { C, and D) but "short-circuits" the students' work (Teachers C } \\
\text { and D). }\end{array}$ & $\begin{array}{l}\text { There is no occurrence } \\
\text { of EP. }\end{array}$ \\
\hline $\begin{array}{l}\text { I Group: VR intro- } \\
\text { duced as illustra- } \\
\text { tion and used by } \\
\text { students. } \\
\text { (Teacher E) }\end{array}$ & $\begin{array}{l}\text { - Teacher proposes a task as challenge, with the introduction of } \\
\text { VR as illustration; } \\
\text { - Teacher synthesises with the use of VR as illustration; } \\
\text { - Teacher requests additional aspects with the use of VR as } \\
\text { illustration. }\end{array}$ & $\begin{array}{l}\text { - Several students' EP } \\
\text { with use of VR as illustra- } \\
\text { tion: interpret; establish } \\
\text { relations; conceptualise; } \\
\text { change representation } \\
\text { format; evaluate critically. }\end{array}$ \\
\hline
\end{tabular}

\section{Discussion}

The results of this study indicate that teachers use different visual representations (VR) in the classroom, and with different functions. All teachers use VR during their lessons; however, only the most experienced teachers use it intensively and with epistemic functions. In those lessons, students use VR introduced by the teacher, but they also introduce and use their own VR. Most of those representations are generated during the development of the inquiry tasks, and teachers with more professional experience can use them to enhance students' EP. These teachers have gained practical professional experience from years of teaching (teachers A and E) and also from their engagement in research in Physical Sciences education. This is consistent with the fact that some essential aspects about the teachers' use of VR can be learned through engagement in scientific research (Roth et al., 1998).

Another significant result concerning the way VR are triggered in the classroom is the fact that the less experienced teachers introduce a large number of VR (mainly as illustrations) but do not request any action of their students that requires using such VR. That is why the most determinant teacher mediation action is the presentation of a task as a challenge. The task must give students acceptable control over their activity and they must know exactly what they need to do to achieve an answer or solution (Lopes, et al., 2008a). From the results, it is also possible to infer that the introduction of VR as illustration, during the task presentation, seems to have as a consequence an increasing vagueness about the purposes of the task and about what students are supposed to do. The use of VR as illustration has wrongly implied the idea that VR may be worth ten thousand words (Larking \& Simon, 1987); however, this is only true 
Elisa SARAIVA, J. BERNARDINO LOPES, J. PAULO CRAVINO, Carla A. SANTOS. How do Teachers of Physical Sciences with Different Professional Experiences Use Visual Representations with Epistemic Functions in the Classroom

if students can understand their meaning. So, when the teacher introduces VR as illustration he must pay careful attention to the task formulation. If the task is not well formulated and does not immediately lead students to the development of EP, the teacher must be aware of that fact in order to take important mediation actions that will scaffold the students' work (e.g., requesting additional aspects). However, the teacher needs to learn how to formulate tasks that make clear, from the beginning, what the purposes of the task are and what is expected from students to produce (Lopes, et al., 2008a).

The results show that the introduction and use of VR as manipulable mediators (MM) are present in episodes of long duration and a large number and variety of students' EP. That is, the use of VR as MM increases the students' EP. This shows that VR, as MM, facilitate students' interaction with epistemic objects according to literature results (Magnani \& Dossena, 2005; Magnani, 2004) and, consequently, promote the development of students' EP. However, as discussed above, even when VR are used as MM, it is also fundamental that the teacher proposes a task as challenge. It is also important that the teacher uses the MM to synthesise or request additional aspects of the students' work.

When teachers introduce VR as illustration, their mediation actions of request for additional aspects (clarifying the students' epistemic work) and synthesis (to reinforce the students understanding) have a positive impact on the development of students' EP. Without these important teacher mediation actions and making explicit the underlying meaning associated (Kozma \& Russel, 1997), the use of VR as illustration, by itself, does not accomplish any epistemic function, i.e., does not promote the development of students' EP. The use of VR as illustrations requires a better scaffold of students' epistemic work, which the most experienced teachers do better.

Besides the introduction and use of VR with epistemic functions, there are other important actions of teacher mediation that, even when they are not related with the use of VR as MM, are determinant for scaffolding the students' epistemic work. Such mediation actions are the epistemic valorisation of the students' work and explicitation of the epistemic statute of student work (done or ongoing). In opposition to that, there are some teacher mediation actions that decrease the students' opportunities to develop EP. Beyond the fact that the inadequate formulation of the task is the most determinant teacher mediation action that will reduce the student's opportunities to develop EP, there are other mediation actions that undermine the occurrence of EP in the classroom. Such actions are: "short-circuit" the students' work (teacher does not allow students opportunities to accomplish the task by themselves); ignore epistemically the students' ideas; devaluate epistemically the students' work (devaluing a potential epistemic practice of the student). In addition, whenever a teacher does not focus on a manageable number of situations (dispersion on the approach), the opportunities to develop students' EP are decreased.

\section{Conclusions}

The most determinant teacher mediation action that triggers the use of VR is the presentation of a task as a challenge. The visual representation (VR) can be introduced in classroom and not used with epistemic functions. It occurs in teachers with less professional experience because the use of VR needs to be learned in a certain context.

The VR can be introduced as manipulable mediators (MM) or illustration. It has epistemic functions as a mediator because the student can use it to interact with the epistemic object. The use of VR as MM facilitates students' interaction with epistemic objects, promotes the development of students' EP, and increases opportunities for their occurrence. That is why, when VR are used as MM, fewer teachers' mediation efforts are required to promote students' EP. Teachers with more professional experience show more use of VR as MM. 
PROBLEMS

OF EDUCATION

IN THE $21^{\text {st }}$ CENTURY

Volume 42, 2012

112 The use of VR as illustration has the potential to promote students' EP if the teacher takes other important mediation actions, like requesting additional aspects or synthesising to reinforce the students' understanding about what they are doing. By itself, the use of VR as illustration does not have epistemic functions. To enable the possibility of having epistemic functions further mediation efforts are necessary, and only an experienced teacher can easily achieve them.

The findings from this study point to the need to develop further research that can help a teacher's professional development about teacher mediation actions concerning the use of VR with epistemic functions.

\section{Acknowledgements}

We acknowledge the support of FCT for the project PTDC/CPE/112303/2009.

\section{References}

Ares, N., Stroup, W. M., \& Schademan, A. R. (2009). The power of mediating artifacts in group-level development of mathematical discourses. Cognition and Instruction, 27 (1), 1-24.

Brooks, M. (2009). Drawing, visualisation and young children's exploration of "Big Ideas." International Journal of Science Education, 31 (3), 319-341.

Carrara, M., Cherubini, P., \& Giaretta, P. (2006). Symposium on "Cognition and Rationality: Part I." Mind \& Society, 5 (2), 167-171.

Cohen, L., Manion, L., \& Morrison, K. (2000). Research methods in education (5th ed.). London: Routledge.

Crawford, T., Kelly, G. J., \& Brown, C. (2000). Ways of knowing beyond facts and laws of science: An ethnographic investigation of student engagement in scientific practices. Journal of Research in Science Teaching, 37 (3), 237-258.

Driver, R., Leach, J., Millar, R., \& Scott, P. (1996). Young people's images of science. Buckingham, UK: Open University Press.

Duschl, R. A. (2000). Making the nature of science explicit. In R. Millar, J. Leach, \& J. Osborne (Eds.), Improving science education: The contribution of research. Philadelphia: Open University Press.

Duschl, R. A. (2008). Science education in three-part harmony: Balancing conceptual, epistemic, and social learning goals. Review of Research in Education, 32 (1), 268-291.

Hand, B., \& Choi, A. (2010). Examining the impact of student use of multiple modal representations in constructing arguments in organic chemistry laboratory classes. Research in Science Education, 40, 29-44.

Hand, B., Gunel, M., \& Ulu, C. (2009). Sequencing embedded multimodal representations in a writing to learn approach to the teaching of electricity. Journal of Research in Science Teaching, 46 (3), 225-247.

Hubber, P., Tytler, R., \& Haslam, F. (2010). Teaching and learning about force with a representational focus: Pedagogy and teacher change. Research in Science Education, 40, 5-28

Jaipal, K. (2010). Meaning making through multiple modalities in a biology classroom: A multimodal semiotics discourse analysis. Science Education, 94, 48-72.

Jiménez-Aleixandre, M. P., \& Erduran, S. (2008). Argumentation in science education: An overview. In S. Erduran \& M. P. Jiménez-Aleixandre (Eds.), Argumentation in science education: Perspectives from classroom-based research (pp. 3-27). Dordrecht: Springer.

Jiménez-Aleixandre, M. P., \& Reigosa, C. (2006). Contextualizing practices across epistemic levels in the chemistry laboratory. Science Education, 90, 707-733.

Kaufman, L., \& Rousseeuw, P. J. (1990). Finding groups in data: An introduction to cluster analysis. Chichester: John Wiley \& Sons, Inc. 
Elisa SARAIVA, J. BERNARDINO LOPES, J. PAULO CRAVINO, Carla A. SANTOS. How do Teachers of Physical Sciences with Different Professional Experiences Use Visual Representations with Epistemic Functions in the Classroom

Kelly, G. J., \& Chen, C. (1999). The sound of music: Constructing science as sociocultural practices through oral and written discourse. Journal of Research in Science Teaching, 36 (8), 883-915.

Kelly, G. J., \& Duschl, R. (2002). Toward a research agenda for epistemological studies in science education. Paper presented at the annual meeting of the National Association for Research in Science Teaching, New Orleans, LA.

Knuuttila, T. (2005). Models, representation, and mediation. Philosophy of Science, 72 (5), 1260-1271.

Kozma, R. (2003). The material features of multiple representations and their cognitive and social affordances for science understanding. Learning and Instruction, 13, 205-226.

Kozma, R., Chin, E., Russel, J., \& Marx, N. (2000). The roles of representations and tools in the chemistry laboratory and their implications for chemistry learning. The Journal of the Learning Sciences, 9 (2), 105-143.

Kozma, R., \& Russel, J. (1997). Multimedia and understanding: Experts and novice responses to different representations of chemical phenomena. Journal of Research in Science Teaching, 34 (9), 949968.

Krippendorf, K. (2004). Content analysis: An introduction to its methodology. Newbury Park, CA: Sage.

Larking, J. H., \& Simon, H. A. (1987). Why a diagram is (sometimes) worth ten thousand words. Cognitive Science, 11, 65-99.

Lemke, J. L. (1998). Multiplying meaning: Visual and verbal semiotics in scientific text. In J. R. Martin \& R. Veel (Eds.), Reading science: Critical and functional perspectives on discourses in science (pp. 87-113). London: Routledge.

Lopes, J. B., Branco, J., \& Jiménez-Aleixandre, M. P. (2011). 'Learning experience’ provided by science teaching practice in a classroom and the development of students' competences. Research in Science Education, 41, 787-809.

Lopes, J. B., Cravino, J. P., Branco, M., Saraiva, E., \& Silva, A. A. (2008a). Mediation of student learning: Dimensions and evidences in science teaching. Problems of Education in the 21st Century, 9 (9), 42-52.

Lopes, J. B., Silva, A. A., Cravino, J. P., Costa, N., Marques, L., \& Campos, C. (2008b). Transversal traits in science education research relevant for teaching and research: A meta-interpretative study. Journal of Research in Science Teaching, 45 (5), 574-599.

Lopes, J. B., Silva, A. A., Cravino, J. P., Viegas, C., Cunha, A. E., Saraiva, E., et al. (2010). Investigação sobre a mediação de professores de Cências Físicas em sala de aula. Vila Real: Universidade de Trás-os-Montes e Alto Douro.

Magnani, L. (2004). Reasoning through doing. Epistemic mediators in scientific discovery. Journal of Applied Logic, 2 (4), 439-450.

Magnani, L., \& Dossena, R. (2005). Perceiving the infinite and the infinitesimal world: Unveiling and optical diagrams in the construction of mathematical concepts. Foundations of Science, 10 (1), 7-23.

Mariotti, M. (2000). Introduction to proof: The mediation of a dynamic software environment. Educational Studies in Mathematics, 44 (1), 25-53.

McNeill, K. L., \& Krajcik, J. (2009). Synergy between teacher practices and curricular scaffolds to support students in using domain-specific and domain-general knowledge in writing arguments to explain phenomena. The Journal of Learning Sciences, 18, 416-460.

Nordmann, A. (2007). Collapse of distance: Epistemic strategies of science and technoscience. In F. Collin (Ed.), Danish yearbook of philosophy (Vol. 41, pp. 7-34): <AU: City?>Museum Tusculanum Press.

Prain, V., Tytler, R., \& Peterson, S. (2009). Multiple representation in learning about evaporation. International Journal of Science Education, 31 (6), 787-808.

Reveles, J., Cordova, R., \& Kelly, G. (2004). Science literacy and academic identity formulation. Journal of Research in Science Teaching, 41 (10), 1111-1144. 
PROBLEMS

OF EDUCATION

IN THE $21^{\text {st }}$ CENTURY

Volume 42, 2012

114

Roth, W. M., McGinn, M. K., \& Bowen, G. M. (1998). How prepared are preservice teachers to teach scientific inquiry? Levels of performance in scientific representation practices. Journal of Science Teacher Education, 9 (1), 25-48.

Sandoval, W. A. (2005). Understanding students' practical epistemologies and their influence on learning through inquiry. Science Education, 89, 634-656.

Sandoval, W. A., Bell, P., Coleman, E., Enyedy, N., \& Suthers, D. (2000). Designing knowledge representations for learning epistemic practices of science. Paper presented at the the annual meeting of the American Educational Research Association, New Orleans.

Sandoval, W. A., \& Reiser, B. J. (2004). Explanation-driven inquiry: Integrating conceptual and epistemic scaffolds for scientific inquiry. Science Education, 88 (3), 345-372.

Santos, C. A., Lopes, J. B., \& Cravino, J. P. (2011). Patterns of didactic decisions made by teachers in physical sciences classrooms. Problems of Education in the 21st Century, 36 (36), 76-89.

Teodoro, V. D., Vieira, J. P., \& Clérigo, F. C. (2000). Modellus, interactive modelling with mathematics (Version 2.01). Monte da Caparica: Faculdade de Ciências e Tecnologia da Universidade Nova de Lisboa.

Toth, E. E., Suthers, D. D., \& Lesgold, A. M. (2002). Mapping to know: The effects of representational guidance and reflective assessment on scientific inquiry. Science Education, 86, 264-286.

Tytler, R., Prain, V., \& Peterson, S. (2007). Representational issues in students learning about evaporation. Research in Science Education, 37 (3), 313-331.

Vygotsky, L. S. (1978). Mind in society. The development of higher psychological process. Cambridge, MA: Harvard University Press.

Wong, D., Poo, S. P., Hock, N. E., \& Kang, W. L. (2011). Learning with multiple representations: An example of a revision lesson in mechanics. Physics Education, 46 (2), 178-186.

Wu, H. K., \& Krajcik, J. S. (2006). Exploring middle school students' use of inscriptions in project-based science classroom. Science Education, 90 (5), 852-873.

Advised by Clara Viegas, Polytechnic of Porto, Porto, Portugal

Received: January 24, 2012

Accepted: March 16, 2012

\begin{tabular}{ll} 
Elisa Saraiva & $\begin{array}{l}\text { Ph.D, Student, School of Sciences and Technology, University of Trás-os-Montes e } \\
\text { Alto Douro, Apartado 1013, 5001-801 Vila Real, Portugal. } \\
\text { E-mail: elisasaraiva@hotmail.com }\end{array}$ \\
\hline J. Bernardino Lopes & $\begin{array}{l}\text { Associate Professor with Aggregation, School of Sciences and Technology, Univer- } \\
\text { sity of Trás-os-Montes e Alto Douro, Apartado 1013, 5001-801 Vila Real, Portugal. } \\
\text { E-mail: blopes@utad.pt }\end{array}$ \\
\hline J. Paulo Cravino & $\begin{array}{l}\text { Assistant Professor, School of Sciences and Technology, University of Trás-os-Mon- } \\
\text { tes e Alto Douro, Apartado 1013, 5001-801 Vila Real, Portugal. } \\
\text { E-mail: jcravino@utad.pt }\end{array}$ \\
\hline Carla A. Santos & $\begin{array}{l}\text { Ph.D, Student, School of Sciences and Technology, University of Trás-os-Montes e } \\
\text { Alto Douro, Apartado 1013, 5001-801 Vila Real, Portugal. } \\
\text { E-mail: carla.manuela.santos@gmail.com }\end{array}$
\end{tabular}

